\title{
Possible Trinity of COVID-19, Diabetes Mellitus, and Retinopathy
}

\author{
(1) Syed Nasir Ali Shah \\ Khyber Eye Foundation Hospital, Peshawar, Pakistan
}

Dear Editor,

On March II, 2020, the World Health Organization declared that the coronavirus 2019 (COVID-19) disease, caused by severe acute respiratory syndrome coronavirus 2 (SARSCoV-2) infection, had become a pandemic (I). Primarily, it presents with pneumonia; however, a few studies have also reported ophthalmological symptoms (2). Conjunctivitis has been the primary ophthalmic complaint and a recent study reported retinal findings in 12 COVID- 19 cases (3). The authors did not mention any systemic illnesses affecting the retina or other existing retinal pathology. In 4 patients, subtle changes in the retina were detected, such as microhemorrhages and cotton wool spots. Additionally, in both eyes of all of the study patients, hyper-reflective lesions in the ganglion cells and inner plexiform were observed on optical coherence tomography examination. Visual acuity was nor$\mathrm{mal}$ and the pupillary reflexes were intact (3).

Diabetic retinopathy (DR) is a common complication of diabetes mellitus (DM), and vision deterioration is often seen in the working-age population (4). Microvascular hemorrhage and a reduction in ganglion cells and inner plexiform layer thickness have been observed in DM animal models (5). Molecular changes, like the levels of endothelial cell adhesion molecules, chemokines, and pro-inflammatory cytokines, detected in DM patients are correlated with DR severity (5).

In severe COVID- 19 cases, high levels of pro-inflammatory cytokines (e.g., tumor necrosis factor alpha and interleu- kin 6) have been observed.5 DM has been reported as risk factor for a poor COVID- 19 prognosis, due to an impaired immune system. Since inflammation plays a key role in aggravating retinal lesions in DM patients, these proinflammatory cytokines can precipitate these lesions or vice versa (6).

It has been observed that viral RNA of SARS-CoV-2 was detectable in the retina of COVID-19 patients and hypothesized that the virus allows entry into host cells (8). Based on published data of COVID-19 cases, we hypothesize that there may be a relationship between DM, COVID-19, and retinal lesions. Angiotensin converting enzyme 2 (ACE2) and transmembrane protease, serine 2 (TMPRSS2) allow SARS-CoV-2 to infect cells (9). Human retinal cells have a low expression of ACE2 and TMPRSS2 in the inner nuclear layers $(10, I I)$. Diabetics have a lack of innate immunity against SARS-CoV-2, which allows for rapid proliferation. Short-term hyperglycemia can depress the innate immunity system (12). Drugs required for DM treatment and complications may lead to over-expression of ACE2 in various organs, which makes DM patients more prone to SARS-CoV-2 infection $(13,14)$. We hope that future studies will evaluate the impact of pharmacological treatments on SARS-CoV-2positive DM patients to assess whether these drugs increase risk of retinal injuries.

In addition to ACE2, the transmembrane glycoprotein basigin (CDI47) has also been reported to be an invasive route for SARS-CoV-2 (I5). CDI47 is expressed in human

How to cite this article: Shah SNA. Possible Trinity of COVID-19, Diabetes Mellitus, and Retinopathy. Beyoglu Eye J 2021 ; 6(2): $158-159$.

Address for correspondence: Syed Nasir Ali Shah, MD. Khyber Eye Foundation Hospital, Peshawar, Pakistan

Phone: +923338418687 E-mail: ophthnasir@hotmail.com

Submitted Date: February 16, 2021 Accepted Date: March 07, 2021 Available Online Date: June 08, 2021

${ }^{\circ}$ Copyright 2021 by Beyoglu Eye Training and Research Hospital - Available online at www.beyoglueye.com OPEN ACCESS This work is licensed under a Creative Commons Attribution-NonCommercial 4.0 International License. 
retinal ganglion cells. Pro-inflammatory cytokines allow it to impair the blood-retina barrier in hyperglycemics (16). This may permit the invasion of retinal cells by SARS-CoV-2 in DM patients, which may also be an interesting topic for future pharmacological studies.

In summary, diabetes is associated with COVID-19 severity and the risk of retinal lesions in patients with COVID-19 may be greater due to the role of pro-inflammatory cytokines and CDI47 in the short- or long-term. These hypotheses need to be explored in clinical and animal models to precisely determine the potential impact of COVID-19 or other systemic diseases. Greater understanding of ocular sequelae in DM patients infected with SARS-CoV-2 should be given priority. In the words of Winston Churchill, "I never 'worry' about action, but only about inaction."

\section{Disclosures}

Peer-review: Externally peer-reviewed.

Conflict of Interest: None declared.

\section{References}

I. Wang LS, Wang YR, Ye DW, Liu QQ. A review of the 2019 Novel Coronavirus (COVID-19) based on current evidence. Int J Antimicrob Agents 2020;55:105948. [CrossRef]

2. Wu P, Duan F, Luo C, Liu Q, Qu X, Liang L, et al. Characteristics of ocular findings of patients with coronavirus disease 2019 (COVID-19) in Hubei province, China. JAMA Ophthalmol 2020; 1 38:575-8. [CrossRef]

3. Marinho PM, Marcos AAA, Romano AC, Nascimento $\mathrm{H}$, Belfort R Jr. Retinal findings in patients with COVID-19. Lancet 2020;395(10237): 1610. [CrossRef]

4. Cheung N, Mitchell P, Wong TY. Diabetic retinopathy. Lancet 2010;376(9735): I24-36. [CrossRef]

5. Wang W, Lo ACY. Diabetic retinopathy: pathophysiology and treatments. Int J Mol Sci 20I8;19(6):I8I6. [CrossRef]

6. Sohn EH, van Dijk HW, Jiao C, Kok PH, Jeong W, Demirkaya $\mathrm{N}$, et al. Retinal neurodegeneration may precede microvascular changes characteristic of diabetic retinopathy in diabetes mellitus. Proc Natl Acad Sci U S A. 2016; I I 3:E2655-64. [CrossRef]

7. Ye Q, Wang B, Mao J. The pathogenesis and treatment of the 'Cytokine Storm' in COVID- 19. J Infect 2020;80:607-13. [CrossRef]

8. Casagrande M, Fitzek A, Püschel K, Aleshcheva G, Schultheiss $\mathrm{HP}$, Berneking $\mathrm{L}$, et al. Detection of SARS-CoV-2 in human retinal biopsies of deceased COVID-19 patients. Ocul Immunol Inflamm 2020;28:72I-5. [CrossRef]

9. Hoffmann M, Kleine-Weber H, Schroeder S, Krüger N, Herrler T, Erichsen S, et al. SARS-CoV-2 Cell Entry Depends on ACE2 and TMPRSS2 and Is Blocked by a Clinically Proven Protease Inhibitor. Cell 2020;181:27I-80.e8. [CrossRef]

10. Tikellis C, Johnston Cl, Forbes JM, Burns WC, Thomas MC, Lew RA, et al. Identification of angiotensin converting enzyme 2 in the rodent retina. Curr Eye Res 2004;29:419-27. [CrossRef] I I. Hamashima K, Gautam P, Lau KA, Khiong CW, Blenkinsop TA, $\mathrm{Li} \mathrm{H}$, et al. Potential modes of COVID-19 transmission from human eye revealed by single-cell atlas. bioRxiv. 2020 Jan I. Doi: https://doi.org/10.1/101/2020.05.09.0856/3. [Epub ahead of print]. [CrossRef]

12. Jafar N, Edriss H, Nugent K. The effect of short-term hyperglycemia on the innate immune system. Am J Med Sci 2016;35I:20I-II. [CrossRef]

13. Cristelo C, Azevedo C, Marques JM, Nunes R, Sarmento B. SARS-CoV-2 and diabetes: New challenges for the disease. Diabetes Res Clin Pract 2020; 164:108228. [CrossRef]

14. Pal R, Bhansali A. COVID-19, diabetes mellitus and ACE2: The conundrum. Diabetes Res Clin Pract 2020;162:108132. [CrossRef]

I5. Wang K, Chen W, Zhou YS, Lian JQ, Zhang Z, Du P, et al. SARS-CoV-2 invades host cells via a novel route: CDI47spike protein. BioRxiv. 2020 Mar 14. Doi: https://doi. org/10.1 I 01/2020.03.14.988345. [Epub ahead of print]. [CrossRef]

16. Arima M, Cui D, Kimura T, Sonoda KH, Ishibashi T, Matsuda S, et al. Basigin can be a therapeutic target to restore the retinal vascular barrier function in the mouse model of diabetic retinopathy. Sci Rep 2016;6:38445. [CrossRef] 